\title{
PROPOSED AMENDMENT TO SECTION SIXTY OF THE BANKRUPTCY ACT
}

IN the interest of pro rata distribution of the debtor's estate among all creditors, ${ }^{1}$ Section $60^{2}$ of the Bankruptcy Act seeks, generally, to void any attempt to secure preference by a creditor who becomes aware of his debtor's insolvency shortly prior to bankruptcy. ${ }^{3}$ The American Bar Association's proposed amendment ${ }^{4}$ raises again the hoary issue of the extent of this

1. Hearings before Committee on the Judiciary on H.R. 8046, 75th Cong., 1st Sess. 121 (1937). "Equality of distribution is the key note of every distribution of estates of insolvent debtors." Analysis of H.R. 12889, 74th Cong., 2d Sess. 187 (1936). See McLaughlin, Aspects of the Chandler Bill to Ament the Bankruptcy Act, 4 U. of Crrr. L. Rev. 369-72 (1937); Oglebay, Proposed Revision of Section 60a of the Bankinuptcy Act: Step Backward, 21 J.N.A. Ref. BANKR. 54, 57 (1947); Comment, 41 Mich. L. Rev. 473, 478 (1942) ; Note, 10 U. of CHr. L. REv. 220, 221 (1943).

2. 30 Stat. 562 (1898), as amended, 32 Stat. 799 (1903), 36 Stat. 842 (1910), 44 StaT. 666 (1926), 52 STAT. 869 (1938), 11 U.S.C. $\$ 96$ (1940), hereafter cited by section only. The portions of the present text of $\$ 60$ relevant to this discussion are:

"(a) A preference is a transfer, as defined in this title, of any of the property of a debtor to or for the benefit of a creditor for or on account of an antecedent debt, made or suffered by such debtor while insolvent and within four months before the filing by or against him of the petition in bankruptcy, or of the original petition under chapter 10,11,12, or 13 of this title, the effect of which transfer will be to enable such creditor to obtain a greater percentage of his debt than some other creditor of the same class. For the purposes of subdivisions a and b of this section, a transfer shall be deemed to have been made at the time when it became so far perfected that no bona-fide purchaser from the debtor and no creditor could thercafter have acquired any rights in the property so transferred superior to the rights of the transferee therein, and, if such transfer is not so perfected prior to the filing of the petition in bankruptcy or of the original petition under chapter $10,11,12$ or 13 of this title, it shall be deemed to have been made immediately before bankruptcy.

"(b) Any such preference may be avoided by the trustee if the creditor receiving it or to be benefited thereby or his agent acting with reference thereto has, at the time when the transfer is made, reasonable cause to believe that the debtor is insolvent. ..."

3. 3 Collier, Bankruptcy 739-50 (14th ed., Moore and Oglebay, 1941) ; 2 GlenN, Fraudulent Conveyances and Preferences $\$ 376$ (1940).

For detailed discussion of the statute, see infra pp. 828-32, 837 et seq.

With the American position that invalidity of a preferential transfer depends upon the creditor's having "reason to know" of the debtor's insolvency, contrast the English ruie making the debtor's intent determinative, 3 ColliER, BANKRUPTCY 759-62; 2 GLENN, op. cit. supra, \$378-9; Glenn, The Diversities of the Preferential Transfer: $A$ Study in Bankruptcy History, 15 CORN. L. Q. 521, 532 (1930).

4. H.R. 2412 and S. 826, 80th Cong., 1st Sess. (1947). Both bills were introduced in March, 1947. Hearings before the Senate and House Judiciary Committees have not yet been scheduled. The Association's draftsmen were Professors John Hanna and James A. McLaughlin, and Messrs. J. Francis Ireton, Milton P. Kupfer and Homer J. Livingston. For discussion of the amendment, see Ireton, $A$ Proposal to Amend Section 60a of the Bankruptcy Act, A6 Corp. Reorg. 257 and n.2 (1947) (giving the history of the proposed amendment); Kupfer and Livingston, Corn Exchange National Banls and Trist Company v. Klauder Revisited: A Supplementary Note, 33 VA. L. REv. 1, 6-12 (1947); McLaughlin, Defining a Preference in Bankruptcy, 60 Harv. L. Rev. 233, 252 et scq. 
policy's application against the secured creditor who conceals the nature of his lien against the debtor's estate until the latter's insecure financial condition dictates disclosure.

Until 1938, transactions such as real property conveyances, ${ }^{\circ}$ chattel mortgages ${ }^{7}$ and equitable liens, ${ }^{8}$ all securing to one specific creditor an interest in the debtor's property, were treated as valid against the trustee even though undisclosed until immediately before bankruptcy. In consequence, general creditors who had relied on the debtor's visible assets in extending credit frequently found themselves suddenly dependent upon largely non-existent estates.

In seeking to ameliorate this injustice, ${ }^{9}$ the draftsmen of the Chandler Act of $1938^{10}$ made no attempt to establish a federal standard of lien notoriety but pinned their requirements to state law. ${ }^{11}$ Accordingly, Section 60 subjects secret liens to attack by the trustee only where local law requires their publication on penalty of subordination in local actions not only to the claims of the debtor's creditors but also to those of bona fide purchasers from him. Manifestly, this gives the trustee powers unavailable to individual creditors acting alone against the estate, a discrepancy justified in the minds of the draftsmen by the iniquity of the secret lien.

(1946). But see Keeffe, Kelly, and Lewis, Sick Sixly: A Proposed Rezision of Section $60 \mathrm{~A}$ of the Bankruptcy Act, 33 CosN. L. Q. 99 (1947) (with a suggested "amendment" to the proposed amendment). Another amendment to $\S 603$, proposed by the National Bankruptcy Conference, has been introduced by Representative Hobbs, (D. Ala.), since this comment was written. The new bill is substantially similar to the A.B.A. proposal herein discussed. H.R. 5834, 80th Cong., 2d Sess. (1948).

5. Every major revision of the bankruptcy laws since 1898 has seen Congressional action against the secret lien, followed invariably, until the Chandler Act, by judicial emasculation. For typical Congressional comment, see 35 Co:sc. Rec. 6937, 6941-3 (1902); 45 Id. at $2271,2273-5,2278-9$ (1910) ; 67 Id. at 6801 (1926) fassim. See also Hirschfeld v. Nogle, 5 F. Supp. 234 (E.D. Ill. 1933) (comment on debates and statutory history). Extensive treatment is given the history of $\$ 60$ in 3 ColrIER, BArrsnuprey 868-91. 921 n.7.

6. Carey v. Donohue, 240 U.S. 430 (1916). See cases cited, 3 Colsuen, Basienumer

7. Martin v. Commercial National Bank, 245 U.S. 513 (1918). See cases cited 3 COLITER, BANKRUPTCY 927 n.14-16.

S. Sextón v. Kessler \& Co., 225 U.S. 90 (1912). See cases cited, 3 Collner, BAsiERUPTCY $881 \mathrm{n} .51$.

9. H. R. REP. No. 1409, 75th Cong., 1st Sess. 30 (1937).

10. 52 Stat. 883 (1938), 11 U.S.C. $\$ 1$ et seq. (1940). The Chandler Act was the result of many years study by the National Bankruptey Conference, an unofficial body representing, among other groups, the American Bar Association, the National Association of Referees in Bankruptcy, the Commercial Law League of America, the National Association of Credit Men, the American Bankers Association, the United States Chamber of Commerce, the American Institute of Accountants and various law schcols. Hearings before Committee on the Judiciary ort $H$. R. 8046, 75th Cong., 1st Sess. 2-3 (1937). Professor MrcLaughin of Harvard, who had long urged revision of $\S 60$, presented the final draft, enacted without change, to the House Committee. Id. at 120-31.

11. For criticism of the dependence of creditors' rights in bankruptcy on varying state law, see Keeffe, Kelly, and Lewis, stpra note 4, at 109-11. 
It is on this point that the proposed amendment ${ }^{12}$ takes exception to the present statute. Under the suggested change, the trustee would be limited to the powers of the individual creditors for whom he acts in collecting the estate.

\section{Section Sixty of the Chandler Act and the Proposed Amendment}

Before attempting appraisal of the amendment's effect in terms of individual security devices, it is necessary to orient the proposal within the con-

12. H. R. 2412, 80th Cong., 1st Sess. (1947), would substitute for the present version of $\S 60 \mathrm{a}$, the following:

"(1) A preference is a transfer, as defined in this Act, of any of the property of a debtor to or for the benefit of a creditor for or on account of an antecedent debt, made or suffered by such debtor while insolvent and within four months before the filing by or against him of the original petition initiating a proceeding under this Act, the effect of which transfer will be to enable such creditor to obtain a greater percentage of his debt than some other creditor of the same class: Provided, however, That this section shall have no application to proceedings under chapter IX of this Act.

"(2) For the purpose of subdivisions $a$ and $b$ of this section, and subject to the provisions of paragraph (3), a transfer shall be deemed to have been made or suffered at the time when it became so far perfected that no creditor obtaining under applicable law by legal or equitable proceedings on a simple contract a lien on such property without a special priority (whether or not such a creditor exists), could acquire, after such perfection, any rights in the property so transferred superior to the rights of the transferee therein, and if such transfer is not so perfected prior to the filing of the original petition initiating a proceeding under this Act, it shall be deemed to have been made immediately before the filing of such original petition: Provided, however, That where real property is transferred for or on account of an antecedent debt, the transfer shall be deemed to have been made at the time when it became so far perfected that no bona fide purchaser from the debtor could acquire, after such perfection, any rights in the property so transferred superior to the rights of the transferee therein.

"(3) A transfer, wholly or in part, for or on account of a new and contemporaneous consideration shall, to the extent of such consideration and interest thereon and the other obligations of the transferor connected therewith, be deemed to be made or suffered at the time of the transfer, unless the applicable law requires the transfer to be perfected by recording, delivery or otherwise, in order that no creditor described in paragraph (2) could acquire, after such perfection, any rights in the property so transferred superior to the rights of the transferee therein. A transfer to secure a future loan, if such loan is actually made, or a transfer which becomes security for a future loan, shall have the same effect as a transfer for or on account of a new and contemporaneous consideration. If any requirement specified in this paragraph (3) exists, the time of the transfer shall be determined by the following rules:

"I. Where (A) the applicable law specifies a stated period of time of not more than thirty days after the transfer within which recording, delivery, or some other act is required, and compliance therewith is had within such stated period of time; or where (B) the applicable law specifies no such stated period of time or where such stated period of time is more than thirty days, and compliance therewith is had within thirty days after the transfer, the transfer shall be deemed to be made or suffered at the time of the transfer.

"II. Where compliance with the law applicable to the transfer is not had in accordance with the provisions of subparagraph $I$, the transfer shall be deemed to be 
voluted statutory scheme for avoidance of preferences. A transfer of the debtor's property to a creditor for an antecedent debt within four months before bankruptcy is a preference, under Section 60 , provided it is made while the debtor is insolvent and results in the creditor's receiving a percentage of his debt greater than that obtained by other equally situated claimants. ${ }^{13}$ In order to invalidate a preference, the trustee must prove that the creditor had reasonable cause to know of the debtor's insolvency. ${ }^{14}$ All of these elements, except the test of greater percentage, ${ }^{15}$ are determined as of the date the transfer was "made"; 16 it is on the method employed to fix that date that the present statute and the proposed amendment differ.

made or suffered at the time of compliance therewith, and if such compliance is not had prior to the filing of the original petition initiating a proceeding under this Act, such transfer shall be deemed to have been made or suffered immediatcly before the filing of such original petition."

13. Section 60 a.

14. Section $60 \mathrm{~b}$. Proof of reasonable cause to belicve that the debtor is insolvent is a question of fact; the burden of proof is on the trustee to overcome the presumption of good faith on the part of a creditor who has received a payment of his debt. See 3 COLLTER, BANKRUPTCY 9S9-1014.

15. Palmer Clay Products Co. v. Brown, 297 U.S. 227 (1936). Before this decision, there had been some conflict as to whether the percentage test should be applied at the time the transfer is executed by the parties, or, as the Palner case preseribed, when bankruptcy resuits. See Palmer Clay Products Co. v. Brown, supra at 228. It is now well settled that the actual effect of the preferential transfer at the time of banlsuptcy is determinable. 3 Colirer, BANKRUPTCY 863-5.

16. Before the Supreme Court decision in Corn Exchange National Bank \& Trust Co. v. Klauder, 318 U.S. 434 (1943), some courts held that even under the Chandler Act, whether a transfer had been executed for an antecedent debt was to be determined as of the date of execution, not necessarily when the Bankruptcy Act considered it "made" Adams v. City Bank \& Trust Co., 115 F.2d 453 (C.C.A. 5th 1940), cert. dericd, 312 U.S. 699 (1941); see Comment, 41 IIrCH. L. Rev. 473 (1942); Notes, 29 CALr. L. REv. 522, 524 (1941), 41 CoL. L. REv. 512 (1941), 36 ILL. L. Rev. 783 (1942), 10 U. of Crr. L. Rev. 220, 222 et seq. (1943) ; In re Talbot Canning Corp., 35 F. Supp. 680 (D. Ard. 1940), 39 F. Supp. 858 (D. Md. 1941), rev'd on other grounds sub nom. Associated Seed Growers v. Geib, 125 F.2d 683 (C.C.A. 4th 1942); Note, 40 Mrcr. L. Rsw. 105 (1941); In re E. H. Webb Grocery Co., 32 F. Supp. 3 (Mr.D. Tenn. 1940). For criticism of these cases and anticipation of the Klander decision, so far as the antecedent debt problem is concerned, see 3 Collier, Bankruptcy 911-4; Hanna, Some Unsolucd Problenis Urder Section $60 \mathrm{~A}$ of the Bankruptcy Act, 43 CoL. L. Rev. 58, 65 (1943); Mfulder, Ambigutics in the Chandler Act, 89 U. PA. L. REv. 10, 22-4 (1940); Salter, Perfection of Tille of a Lienor under Section 60 of the Bankinuptcy Act, 48 Coss. L. J. 242, 243 (1943); Snedelser, Security Devices as Preferences Under the Bankruptcy Act, 8 Mo. L. REv. 85, 88 (1943); Note, 10 U. of CEI. L. Rev. 220-4 (1943). But see Wolfe, Current Bantrustcy Controversies, 17 TEMrP. L. Q. 64 (1942).

There is no doubt that the draftsmen intended all elements of a preference except the greater percentage test to be tested as of the time the transfer vas "made." AfcLaughilin, Defining A Preference in Baskruptcy, 60 HARv. L. REv. 233, 245 (1946). 


\section{Section Sixty of the Chandler Act}

Section 60 now treats a transfer as "made" only when it has been

"so far perfected that no bona-fide purchaser from the debtor and no creditor could thereafter have acquired any rights in the property so transferred superior to the rights of the transferee therein. . .."

Unless the transferee has fully publicized the nature of his interest in the debtor's property to the extent required by local law, the perfection test considers as subsequent in law a transfer simultaneous in fact. If not so perfected, the transfer is in law deemed "made" immediately before bankruptcy ${ }^{17}$ for a debt consequently "antecedent," although, in fact, execution of the transfer and creation of the debt may have occurred simultaneously. Accordingly, the creditor who wishes to protect his security interest from possible invalidation under the preference section must now do everything within his power "in order to make the transfer so complete that it would be good against the whole world." 18

Two decisions applying this test to assignments of accounts receivable have particularly aggravated the agitation for amendment. In Corn Exchange National Bank \& Trust Co. v. Klauder, ${ }^{19}$ applicable local law permitted a creditor-assignee to perfect his interest against a subsequent bona fide purchaser only by notifying the obligor of the assignment. Since no notice had been given, the Supreme Court viewed the transfer as "made" immediately prior to bankruptcy and held it, in consequence, subject to attack.

In re Vardaman Shoe Co., ${ }^{20}$ a district court decision, carried to a logical extreme the Klauder dictum that,

"So long as the transaction is left open to possible intervening rights to ... . [a subsequent bona fide purchaser], it is vulnerable to the intervening bankruptcy." 21

Here, unlike the Klauder situation, local law validated the assignment of accounts receivable when executed; a subsequent bona fide transferee could

17. Section 60a.

18. Weinstein, The Bankruptcy Law of 1938120 (1938).

19. 318 U.S. 434 (1943). The aftermath of this decision has seen a plethora of comment. See Douglas, Assigned Accounts as Affected by Section 60a of the Bankruptcy Act and the Provisions of State Law with Reference Thereto, 19 J. N. A. REF. BANKR. 11 (1944); Hanna, Some Unsolved Problems Under Section 60A of the Bankruptcy Act, 43 CoL. L. REv. 58, 69 et seq. (1943) ; Kupfer and Livingston, Corn Exchantgc National Bank \& Trust Company v. Klauder Revisited: The Afterntath of its Implications, 32 VA. L. Rev. 910 (1946); Montgomery, Review of Supreme Court Ruling on Assigmment of Accoututs Receivable, 17 J. N. A. REF. BANkr. 119 (1943). See also 3 ColrIer, Bankruptcy 70-2 (1946 Supp.); McLaughlin, Defining a Preference in Bankruptcy, 60 Harv. L. Rev. 233, 248-50 (1946); Notes, 29 CoRN. L. Q. 105 (1943), 18 J. N. A. Ref. BANkr. 25 (1943), 22 Neb. L. Rev. 134 (1943), 17 TeMr. L. Q. 461 (1943), 29 VA. L. REv. 1067 (1943).

20. 52 F. Supp. 562 (E.D. Mo. 1943).

21. Corn Exchange National Bank \& Trust Co. v. Klauder, 318 U.S. 434, 437 (1943) (emphasis added). 
prevail, however, by taking additional steps against the obligor, such as securing a judgment or effecting a novation. ${ }^{22}$ The court, literally applying both the Klauder dictum and Section 60 , reasoned that it was still theoretically possible for a subsequent bona fide purchaser to prevail over the initial assignee; accordingly, the transfer was held not fully perfected before bankruptcy intervened.

The Klauder decision does little more than spell out the existing law of preferences in a factual context. ${ }^{23}$ Local law required that the transfer be accorded certain publicity. The creditor failed to divulge his interest in the debtor's estate and consequently became a secret lienor obnoxious to Section 60. Unfortunately In re Vardaman was not appealed; ${ }^{24}$ it has, however, been justly condemned. ${ }^{25}$ Not only did the assignee comply with local publicity requirements, but the transfer, itself, under applicable law, was fully perfected at the time of execution. That the creditor's claim was subject to possible future divestment upon the occurrence of certain conditions was

22. The "Massachusetts rule" applied by the court has been codified by the American Law Institute:

"Any assignee who purchases his assignment for value in good faith without notice of a prior assignment, and who obtains

(i) payment or satisfaction of the obligor's duty, or

(ii) judgment against the obligor, or

(iii) a new contract with the obligor by means of a novation, or

(iv) delivery of a tangible token or writing, surrender of which is required of the obligor's contract for its enforcement,

can retain any performance so received and can enforce any judgment or novation so acquired, and, if he has obtained a token or writing as stated in subclause (iv), can enforce against the obligor the assigned right...." REstaterent, Co:innacts $\S 173$ (b) (1932).

Faced with a conflict of laws problem, the court avoided determining whether the Massachusetts rule or that used in the Klauder case applied by holding that the trustee could recover under either. In addition, therefore, to the fact that the case was never appealed and that its interpretation was misguided, the Vardamon rule may also be attacked as dictum.

23. For approval of the Klatter decision see Oglebay, stupra note 1, at 55, 56; 3 Collier, Bankruptcy 71, 72 (1946 Supp.). Professor Glenn anticipated the application of $\$ 60$ to accounts receivable assignments in this manner. 2 GLenz, FrsubouEir Co:veyances and Preferences \$534. But see Cohen and Gerber, Mortgages of Accoumis Receivable, 29 GEo. L. J. 555, 572-3 (1941); Hamilton, The Effect of Scetion Sirty of the Bankruptcy Act upon Assignntents of Accounts Reccivable, 26 VA. L. REv. 169 (1939); Neuhoff, Assignment of Accounts Receizable as Affectcd by the Chandler Act, 34 InL I. REv. 538 (1940). Professor MícLaughlin, a supporter of the proposed amendment, admits that "[t] he decision upon the facts can scarcely be attacked as without reasonable basis. ..." McLaughlin, Defining a Preference in Bankmpicy, 60 Hasr. L. REr. 233, 248 (1946).

24. Apparently, the proceedings were not even contested. The matter soon breame moot; the bankrupt was shortly reorganized. Brief for Appellees, p. 23, In re Rosen, 157 F.2d 997 (C.C.A. 3d 1946).

25. Kupfer and Livingston, supra note 19, at 916-9; MfcLaughlin, susfre note 23, at 249-50; Oglebay, supra note 1, at 56. But see Snedeker, Sccurity Deciecs and Scc. 60A of the Chandler Act, 22 ORE. I. Rev. 307, 314-7 (1943). 
immaterial. Section 60 measures the trustee's voidability powers with a bona fide purchaser test of perfection; it does not grant him the retroactive status ${ }^{26}$ of a bona fide purchaser, who by subsequent further action might prevail over the transferee's interests. ${ }^{27}$

\section{Criticisms of Section Sixty of the Chandler Act}

The Klauder and Vardaman decisions are said to epitomize the two fundamental evils flowing from Section 60's present form. Even critics who concede that In re Vardaman may be atypical complain that many types of security transactions and commercial practices, hitherto commonly accepted and employed, are now threatened with invalidation by the debtor's bankruptcy. ${ }^{28}$ In addition, they doubt the underlying wisdom of the bona fide purchaser test of perfection in measuring the trustee's powers to avoid preferences.

26. Most commentators support this proposition. See, e.g., 3 CoLLIER, BANKrouptcr 917-20; 2 Glenn, Fraudulent Conveyances and Preferences $\$ 488$; Glenn, The Chandler Act and the Trustee as a Bona Fide Purchaser: A Supplementary Note, 25 VA. L. REv. 885 (1939); Oglebay, supra note 1, at 58. All three cite the equity of a vendor who may rescind because of the bankrupt's fraud as a sample third party right, previously recognized as a matter of course in bankruptcy, which would be cut off by giving the trustee the status of a bona fide purchaser.

27. In the Klauder situation, to prevail, a subsequent bona fide purchaser would also have had to take further action, i.e., notify the account-debtor of the assignment, in order to acquire a superior right in the assigned accounts. Hanna, Some Unsolved Problems sunder Section $60 \mathrm{~A}$ of the Bankruptcy Act, 43 CoL. L. REv. 58, 71 (1943). But, unlike the Vardaman situation, see note 22 supra, "[t]he act that the bona fide purchaser had to do after his purchase in order to prevail was the simple, easy one of giving notice. This did not require litigation, or even the consent or acquiescence of any third party, and thus might be described as a natural incident or corollary of the standing of the hypothetical second assignee as a bona fide purchaser." McLaughlin, Defining a Prefercnee in Bantiruptcy, 60 HARv. L. Rev. 233, 249 (1946). Moreover, under law applicable in the Klautder case the assignment to the preferred creditor was not perfected until notification. But see Martin, Substantive Regulation of Security Devices Under the Bankruplcy Power, 48 CoL. L. REv. 62, 64-5 (1948).

28. "Such drastic treatment of a firmly established business practice (assignment of accounts receivable) has no relation at all to the legitimate purposes of a preference statute." Ireton, supra note 4, at 264. McLaughlin, Defining a Preference in Bankruptcy, 60 HARv. L. REv. 233, 251 (1946). Oglebay treats this objection none too kindly. Oglebay, supra note 1, at 59. See also 3 Collirer, BankRuptcy 916.

Some commentators predicted an immediate curtailment of accounts receivable financing as a direct result of the Klauder decision. McLaughlin, supra, at 251; Snedeker, Security Devices under Sec. $60 \mathrm{~A}$ of the Chandler Act, 22 ORE L. Rev. 307, 317 (1943). However, replies to a questionnaire distributed by the American Bankers Association indicate that employment of this security device has multiplied as a direct result of legislation compelling its public recordation, although the notoriety thereby achieved would scem to be greater than that attending application of the rule which controlled the Klander decision. Legal Dept., Asrer. Bankers Ass'n, Reports on Operation of Filing Statutes in California and Missours 3 (January, 1947). Thomas B. Paton, Assistant General Counsel of the Association, stated: "It is my opinion that recordation legislation which brings 
Section 60 was specifically recast in order to force the commercial world to alter several security transactions long judicially supported. 2 It may be urged that the practically mandatory requirement that public notice be given of the nature and extent of the debtor's borrowing injures the latter's credit standing and militates against his securing the additional funds necessary to prolongation of the business. $\$ 3$ But "to refrain from giving notice, in order ... not to hurt the debtor's credit ... is to urge the very fraud which is aimed at by all the rules protecting creditors against secret liens." 31

With greater force, critics point out that literal interpretation of the present statutory language menaces certain types of security transactions which are not fully perfectible against bona fide purchasers, despite compliance with local recordation statutes. ${ }^{32}$ Literal application of Section 60 would also categorize any transfer not perfected with precise simultaneity into one for an antecedent debt. ${ }^{33}$ But fear resulting from attenuated logic hardly warrants substantial weakening of an effective statute. Certainly the creditor who fully obeys local law by providing the world with notice of his interest in the debtor's property is not the person against whom Section 60 is aimed. Equally, where perfection is completed with reasonable promptness,

accounts receivable financing out in the open naturally has a wholesome effect upon the whole business and this non-secret lien feature has drawn many banlss into the ficld." Communication to YAIE LAw JoURNAL, January 15, 1948.

29. "You are going to have taken away some advantages that some people have enjoyed, and certain practices are going to be altered to some extent. But you have that every time you pass any kind of a commercial law." Statement by Professor MeLaughlin, Hearings before Committee on the Judiciary on $H . R$. 8046, 75th Cong., 1st Sess. 125 (1937). "[F]or thirty-five years Congress has consistently reached out to strilie down secret transfers, and the courts have with equal consistency found its efforts faulty or insufficient to that end. Against such a background, $\$ 60 \mathrm{a}$ was drawn. ..." Corn Exchange National Bank \& Trust Co. v. Klauder, 318 U.S. 434, 438-9 (1943).

30. See Comment, 44 YaIE L. J. 639 (1935), to the effect that secrecy is the essence of successful operation of accounts receivable finaneing. The fear that the Klassder decision's requirement of publicity would kill accounts receivable financing has achieved no factual support. See note 28 supra.

31. Comment, 41 MirCH. L. REv. 473, 479 (1942).

32. Such "imperfectible transfers" include the chattel mortgage of a stock in trade, the conditional sale for resale, the trust receipt, and the factor's lien, all discussed infra pp. 850-3. See Hanna, Some Unsolved Problems Under Section 60A of the Banteripiey Act, 43 CoL. L. Rev. 58, 73 (1943) ; Ireton, supra note 1, at 263-5; Keefie, Kelly, and Lewis, supra note 4, at 100-3; Foreword by Hanna to Koessler, Assignment of Accousuts Reccivable, 33 Calfr. L. Rev. 40, 43-4 (1945); MreLaughlin, Defining a Preferenee in Bantrubtcy, 60 HARv. L. Rev. 233, 251 (1946). But see Oglebsy, supra note 1, at 59.

33. For example, a chattel mortgage executed for an adequate consideration but unrecorded until the following day, would be deemed "made" on the date of recordation and so would become a transfer for the antecedent debt incurred the day before. This result is envisaged by Ireton, supra note 4, at 262, 271, and by Keeffe, Kelly, and Lewis, sufres note 4 , at 105 . Section $60 \mathrm{a}$ (3) I and II of the proposed amendment, sispa note 12, would avert this danger by providing for a limited period, not to exceed thirty days, during which subsequent perfection of the transfer would relate back to the date of execution. 
fairness compels that the process be regarded as a continuous transaction "made" at the time of actual execution. ${ }^{34}$

In addition to criticism leveled at the application of Section 60 to particular types of security transactions, the over-all allegation is made that the trustee's powers therein conferred are disproportionate to the function he performs in avoiding preferential transfers. Would-be amenders assert that the retroactive test should not permit the trustee to accomplish that which individual creditors, acting alone, could not achieve. Where local law permits certain types of "secret" transfers as against the transferror's general creditors, it is argued that such transactions should not be invalidated by the trustee, who, after all, acts only in behalf of these very same creditors..$^{88}$

The radically changed situation represented by the debtor's bankruptcy is totally overlooked by this argument. ${ }^{36}$ In a struggle between an individual

34. Assuredly the purposes of $\$ 60$ are not served by turning security transactions into foot races. See 3 Collter, Bankruptcy 912 n.41; Oglebay, supra note 1, at 56 n.37; Note, 10 U. of CHr. L. Rev. 220, 223-4 and n.16 (1943). As pointed out by these commentators, the doctrine of "continuous transaction" is scarcely foreign to bankruptcy. In re Coombs, 37 F. Supp. 495 (W.D. Mo. 1940); In re MeManus Motors, 27 F. Supp. 113 (D. Mass. 1939) ; cf. Chichester v. Commercial Credit Co., 37 Cal. App.2d 439, 99 P.2d 1083 (1940). In In re E. H. Webb Grocery Co., 32.F. Supp. 3 (M.D. Tenn. 1940), a chattel mortgage executed on Sept. 15, 1938, was recorded on Sept. 16, 1938; the date of bankruptcy was Jan. 16, 1939. The continuous transaction rationale rather than the fallacious "antecedent debt" interpretation, discussed note 16 supra, would have supported the court's holding.

Whether the transaction involved is continuous depends on the particular facts. National City Bank of New York v. Hotchkiss, 231 U.S. 50, 58 (1913). It would seem preferable to leave the matter to the court's discretion, rather than to allow altomatically a thirty-day "relation-back" period in the manner provided by the proposed amendment, note 12 supra. Tolerance of excusable delays does not necessitate light treatment of the transferee who waits twenty-nine days to record in the local courthouse.

35. Ireton, stipra note 4, at 261; Hanna, Some Unsolved Problems Under Section $60 \mathrm{~A}$ of the Bankruptcy Act, 43 CoL. L. REv. 58, 61 (1943); Foreword by Hanna to Kocssler, supra note 32, at 44; McLaughlin, Defining a Preference in Bankrupicy, 60 HARv. L. REv. 233, 253-5 (1946); American Bar Association, Section on Corporation, Banking and Mercantile Law, 1 Bus. Law., No. 1, pp. 10-11 (1946).

The desire for limitation of this type is not new. See Curtis, The Position of a Tristec in Bankruptcy with Reference to Invalid Transfers or Liens, 5 CoL. L. REv. 584, 590 (1905). Professor McLaughlin, in 1927, suggested an amendment to $\S 60$, to provide that "no transfer shall be regarded as made until such steps are taken as are necessary to make it valid against creditors of the sort whose rights, remedies and powers are vested in the trustee by ... Section 47a (2) [now 70c]." McLaughlin, Amendment of the Bankruptcy Act, 40 HARv. L. REv. 341, 390 (1927). By 1938, he was supporting the bona fide purchaser test, however. See note 10 supra. Professor McLaughlin has changed his mind once more, for he is an ardent advocate of the proposed amendment. McLaughilin, Defining a Preference in Bankruptcy, 60 HARv. L. Rev. 233, 245 (1946). He explains that the present $\$ 60$ was an "experiment" thought necessary to overcome strict judicial construction in the past. "Fears that such legislation might go too far were quieted by contemplation of what was deemed to be the established tradition of strict construction." Ibid.

36. Accepting the rationale of this argument, the "logical" conclusion would seem to be that $\S 60$, in itself, is an anomaly, since at common law the preference is perfectly per- 
creditor and the holder of a secret lien, it is well within the province of local law to control the equities; both are contestants in the race of diligence and the victory or defeat of either affects none but the participants. But banlruptcy substitutes for the race of diligence achievement of its own objective -preservation of the estate, during the period of insolvency preceding banlruptcy, for equitable distribution to all creditors. The secret transfer, regardless of its validity apart from bankruptcy, is inimical to this purpose. If such a transaction, unpublicized until immediately before banlruptcy, is subsequently validated as against the trustee, there is a real diminution of the assets upon which other creditors have relied in dealing with the debtor and in refraining from prosecuting claims to judgment. ${ }^{S t}$

\section{The Proposed Amendment}

After nearly half a century's struggle to enable the trustee to strike effectively at the secret lien, it is now proposed to amend Section 60 by providing:

" $[\mathrm{A}]$ transfer shall be deemed to have been made or suffered at the time when it became so far perfected that no creditor obtaining under applicable law by legal or equitable proceedings . . . a lien on such property ... could acquire, after such perfection, any rights in the property so transferred superior to the rights of the transferee therein ..." 33

In short, a transfer to be deemed "made" would need be perfected only against subsequent lien creditors, instead of bona fide purchasers.

\section{Perfection of a Transfer Under Section Stxty: The LAty Now and The Proposed AMindurent}

To evaluate the success of the proposed amendment in countering the alleged flaws in Section 60 and the cost at which this objective would be achieved, it is necessary to consider the procedure required to "perfect" the various major types of security transactions under the present and suggested law of preferences. ${ }^{39}$

\section{The Equitable Lien}

Before the Chandler Act, it was possible to validate virtually every transfer of the debtor's property made shortly prior to bankruptcy by finding a

missible; it is invalid only by statute. 1 Grenn, Fraudurent Comveyarices nid PreferENCES $\$ 289$. To permit the trustee to invalidate any preference allows him to accomplish that which individual creditors, acting alone, could not themselves achieve.

37. Professor Hanna insists that creditors rely not on the debtor's ostensible assets but rather on his financial statements and credit-rating. Hanna, Some Unisole'cd Problens under Section 60A of the Bankruptcy Act, 43 CoL. L. REv. 58, 69-70 (1943). But see note 92 infra.

38. H. R. 2412, S. 826, S0th Cong., 1st Sess. (1947). For the full text of the amendment, see note 12 supra.

39. See 3 Collieg, Banksuptcy 920-84 for extensive treatment of the perfection of various types of security transactions before 1938 and under the present law. 
previously made bona fide agreement to create or give security. Equity, under such circumstances, creates a charge upon the property so affected, 10 which is binding upon the parties, and, some times, even against third persons. Until 1938, performance of the act necessary legally to perfect the equitable lien, i.e., recordation or possession of the res, uniformly was held to "relate back" to the execution of the initial agreement. Unless the original agreement constituted a preference, the transfer was not voidable by the trustee, even though it might not have been publicly disclosed until immediately before bankruptcy. ${ }^{41}$

As between innocent general creditors and an individual lienor who normally is entitled to specific performance of the promise upon which he has relied, the latter must yield in bankruptcy. ${ }^{42}$ The perfection test prescribed by the Chandler Act prohibits the application of the equitable lien against the trustee, ${ }^{43}$ since the equitable rights flowing from an agreement to give security are always subject to divestment by a bona fide purchaser. ${ }^{44}$ The

40. Although rarely so discussed, the lien apparently stems from the equitable notion of unjust enrichment to the borrower at the expense of the creditor who has advanced money or otherwise acted in reliance. The doctrine theoretically operates only when the court discovers an intent by the parties to create a charge supported by adequate consideration, on specifically identifiable property. More realistically, allowance of the lien "turns on delicate appraisals of facts and upon the deciding authority's sense of justice." Britton, Equitable Liens-A Tentative Analysis of the Problem, 8 N. C. L. REv. 388, 394 (1930). For general discussion of the equitable lien see JoNEs, LIENs $\$ \$ 27-96$ (1914); LAWRENCE, EQUITY JURISPRUdENCE $\$ \$ 209$, 234-44 (1929) (equitable assignments) ; Mc-

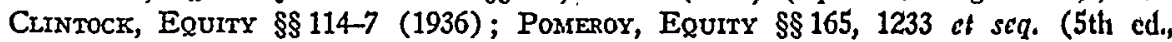
Symons, 1941) ; RestateNent, Restitution $\$ 161$ (1937). For equitable mortgages sec WatSH, EQUity 129 (1930); WrLtsזE, Mortgages $\$ \S 32-38$ (1939); Walsh, Equitablc Mortgages, 9 N. Y. U. L. Q. 429 (1932) ; Stone, The "Equitable Mortgage" in Ncw York, 20 Cot. L. Rev. 519 (1920). For equitable pledges see 1 Glens, Fraudurent Conveyances AND PReferences $\$ \S 292$ et seq., 481; Restatement, Security $\S 10$ and pp. 30-2 (1941).

41. Typical was the leading case of Sexton v. Kessler \& Co., 225 U.S. 90 (1912). An unrecorded agreement by the bankrupt to pledge securities was held to have created an equitable lien in favor of the pledgee; delivery of the securities within four months before bankruptcy "related back" to the date of the original agreement and did not constitute a preferential transfer.

For general discussion of the equitable lien in bankruptcy, see Britton, supra note 40 ; 3 ColmIER, BankRuptcy 875-91, 975-82; Glenn, The Equitable Pledge, Creditors' Rights and the Chandler Act, 25 VA. L. Rev. 422 (1939); Horack, Insolvency and Specific Pcrformance, 31 Harv. L. Rev. 702 (1918); McLaughlin, Amendment of the Bankruptcy Act, 40 HaRv. L. Rev. 341, 383-91 (1927); Comment, 34 Yale L. J. 891 (1925) ; Notes, 37 Cor. L. Rev. 621 (1937), 24 Col. L. Rev. 68 (1924), 12 Mins. L. Rev. 378 (1928).

42. Note, however, that the equitable lien by definition is never perfected.

43. The draftsmen of the Chandler Act left small doubt of their intention to stamp out the doctrine's application in bankruptcy. Hearings before Committee on Judiciary on H. R. 8046, 75th Cong., 1st Sess. 122-3 (1937) ; H. R. REP. No. 1409, 75th Cong., 1st Sess. 30 (1937); MeLaughlin, Defining a Preference in Bankruptcy, 60 HARv. L. REv. 233, 245 (1946). See Corn Exchange National Bank \& Trust Co. v. Klauder, 318 U.S. 434,438 (1943).

44. Pomeroy, EQuity $\$ \$ 743,766$; Restatement, Restitution $\$ 172$ (1937). 
equitable lienor, to be protected against his debtor's insolvency, must now immediately publicize the nature of his interest in the latter's property, instead of delaying legal perfection until bankruptcy appears imminent. ${ }^{45}$

The proposed amendment would revive the "relation back" doctrine and the consequent protection of the equitable lien against the trustee, 19 at least to the extent that it is preferred by local law over the claims of lien creditors. The exact magnitude of the change depends upon an analysis of the law in forty-eight jurisdictions; the cases are many, however, where a judgment or attachment creditor is said to acquire an interest in the debtor's property no greater than that possessed by the debtor himself at the time of levy, and must yield, therefore, to a prior equitable lienor." The history of Sec-

45. Matter of Seim Construction Co., 37 F. Supp. 855 (D.Md. 1941). For excellent evaluation and correct application of the policy of $\$ 60$, see Gins v. Alaurer Plumbing Supply Co., 148 F.2d 974 (C.C.A. 2d. 1945). There an agreement to pledge was held to create an equitable pledge; however, since the chattel rested in the hands of a prior pledgee, creditors were not deceived by the debtor's visible assets. The transfer was accordingly held "made" on the date of the original agreement. Conira: Associated Seed Growers v. Geib, 125 F.2d 683 (C.C.A. 4th 1942), reversing Miatter of Talbot Canning Co., 35 F. Supp. 680 (D. Mfd. 1940); Matter of Lion Overall Co., 48 F. Supp. 442 (S.D.N.Y. 1942). In view of the Klander decision, these latter two cases can no longer be considered good law; the courts in both relied upon Union Trust Co. of $21 \mathrm{~d}$. จ. Townshend, 101 F.2d 903 (C.C.A. 4th 1939), cert. denicd, 307 U.S. 646 (1939), which, applying the pre-1938 law, validated an equitable lien as of the date of the original agreement, and were cited by Justice Roberts in his sole dissent in the Klander case, 318 U.S. 434, 441-2 (1943). But see Matter of Soss, 52 F. Supp. 123, 125 (D. Del. 1943), decided one balf a year after the Klander case. There, the court apparently missed completely the change wrought by the 1938 amendment, saying that taling of possession under a valid equitable lien relates back to the date of the original agreement between the parties for purposes of $\$ 60$.

46. This result, of course, is the major defect in the proposed amendment and has been criticized by Oglebay, supra note 1, at 58-9 and Keeffe, Kelly and Lewis, supra note 4, at 106-9. To remedy the defect, the last named writers suggest that there be inserted in subsection (2) of the proposed bill, supra note 12, a proviso: "for the purposes of this section such a creditor shall be deemed to have an interest superior to that of any cquitable lienor." Besides offering to the courts the obvious out of designating the "equitable lienor" by some other appellation, the proposed amendment, as modified by this suggestion, would still strike down the Klauder result as applied to accounts reccivable assignments and protect the pledgee who has permitted the pledgor to retain temporary possession. See pp. 852-3 infra. Professor Hanna defends this effect of the proposed amendment: "If a state believes that certain equitable interest, specially in respect of land, should prevail over judgment creditors, that . . . is the business of the state." Hanna, Preferenecs in Barkruptcy, 15 U. of CHI. L. Rev. 311, 331 (1948).

47. Equitable lien good against lien of judgment creditors: Union National Bank of Wilmington v. Topkis Bros. Co., 23 Del. Ch. 59, 2 A.2d 148 (Ch. 1938); Royal Insurance Co. v. Simon, 20 Del. Ch. 297, 174 Atl. 444 (Ch. 1934); Union Trust Co. จ. Biggs, 153 Md. 50, 137 Atl. 509 (1927); Smithhurst v. Edmunds, 14 N. J. Eq. 408 (1862); Dwight v. Newell, 3 N.Y. 185 (1865); Dufur Oil Co. v. Enos, 59 Ore. 528, 117 Pac. 457 (1911) ; Charlottesville Hardware Co. v. Perkins, 118 Va. 34, 86 S.E. 869 (1915).

Equitable lien good against lien of attachment creditors: Inderrieden Co. v. Allen, 
tion 70 (c) ${ }^{48}$ confirms the fear that the proposed amendment would greatly curtail the trustee's power under Section 60; before the Chandler Aat went into effect, there were many instances where the trustee's statutory position under Section 70 (c) as a lien creditor, with respect to defending the debtor's property at the time of bankruptcy, was not sufficient to defeat the claims of an equitable lienor against the estate. ${ }^{49}$

\section{Conveyances of Real Property and the Chattel Mortgage}

The Klauder decision makes clear that, under the Chandler Act, no conveyance of real property or chattel mortgage is "made" until the transferee has fully perfected his interest against the entire world by either possession or recordation..$^{50}$ The proposed amendment preserves the bona fide purchaser test of perfection so far as real property transfers are concerned; ${ }^{01}$

176 Ill. App. 301 (1st Dist. 1913) ; City National Bank of Marshalltown v. Crahan, 135 Iowa 230, 112 N.W. 793 (1907) ; Johnson v. Darr, 114 Tex. 516, 272 S.W. 1098 (1925).

Equitable lien good against receiver or assignee for benefit of creditors: Burrowes v. Nimocks, 35 F.2d 152 (C.C.A. 4th 1929) ; McFerran v. Louisville Title Co.'s Receiver, 254 Ky. 362, 71 S.W.2d 655 (1934); Klaustermeyer v. Cleveland Trust Co., 89 Ohio St. 142, 105 N.E. 278 (1913).

Equitable mortgage arising from mortgage agreement not complying with legal requirements good against lien creditors of mortgagor: Fitzgerald v. Fitzgerald, 97 Kan. 408, 155 Pac. 791 (1916) ; Cramer v. Roderick, 128 Md. 422,98 Atl. 42 (1916); Rutherford National Bank v. H. R. Bogle and Co., 114 N. J. Eq. 571, 169 Atl. 180 (Ch. 1933); Robinson v. Williams, 22 N.Y. 380 (1860). See also 1 GLENN, FrAUdulent ConveYs NCES and Preferences $\$ \$ 19,151$; Restatement, Restitution $\$ 161$, comment $c$ (1937).

48. Until 1938, what is now $\$ 70$ (c) was $\$ 47$ (a). 36 SrAT. 838 (1910).

49. E.g., Whiteside v. Rocky Mountain Fuel Co., 101 F.2d 765 (C.C.A. 10th 1938), cert. denied, 307 U.S. 640 (1939) ; Tobin v. Insurance Agency Co., 80 F.2d 241 (C.C.A. 8th 1935); Del Rio Bank \& Trust v. Cornell, 57 F.2d 142 (C.C.A. 5th 1932); In rc Miller-Rose Co., 36 F.2d 203 (C.C.A. 7th 1929); Beacon Trust Co. v. Dolan, 27 F.2d 247 (C.C.A. 1st 1928); In re Dier, 296 Fed. 816 (C.C.A. 3d 1924), cert. denied, 265 U.S. 584 (1923); Hopkins v. National Shawmut Bank, 293 Fed. 884 (C.C.A. 5th 1923), cert. denied, 263 U.S. 722 (1921); Lewin v. Telluride Iron Works Co., 272 Fed. 590 (C.C.A. 8th 1921); In re Hollins, 215 Fed. 41 (C.C.A. 2d 1914); In re Plantations Co., 270 Fed. 273 (E.D. Pa. 1921); Gage Lumber Co. v. McEldowney, 207 Fed. 255 (C.C.A. 6th 1913); Barker Piano Co. v. Commercial Security Co., 93 Conn. 129, 105 Atl. 328 (1918); Schoenherr v. Van Meter, 215 N.Y. 548, 109 N.E. 625 (1915).

50. Matter of Cox, 132 F.2d 881 (C.C.A. 7th 1943) (unrecorded real property mortgage); In re Greenberg, 48 F. Supp. 3 (D. Mass. 1942) (unrecorded chattel mortgage). But cf. Adams v. City National Bank, 115 F.2d 453 (C.C.A 5th 1940) (discussed sipra note 16). Before 1938, the trustee could not move against real property conveyances and chattel mortgages belatedly perfected if local recordation statutes protected only the debtor's lien creditors and bona fide purchasers. Carey v. Donohue, 240 U.S. 430 (1916).

51. Section 60a (2), H. R. 2412, 80th Cong., 1st Sess., note 12 supra.

As Oglebay, supra note 1, at 58, points out, the earlier drafts of the proposed amenclment did not include this exception. Manifestly inconsistent with the theory of the amendment as a whole, it was evidently added to avoid revival of the rule of Carey v. Donohue, 240 U.S. 430 (1916). Ireton, supra note 4, at 270-1; McLaughlin, Defining a Preference in Bankruptcy, 60 Harv. L. Rev. 233, 255 (1946). In Carey v. Donohuc, supra, the trustee could not avoid a real property conveyance belatedly recorded where local leg- 
since all jurisdictions invalidate unrecorded chattel mortgages as against lien creditors, ${ }^{52}$ the amendment's adoption would not change the current law with respect to these two types of transfers.

\section{The Conditional Sale}

Before 1938, a preference was defined in part as a "transfer . . . of any of ... [the debtor's] property ... to anyone of his creditors. . . ." 53 In Bailey v. Baker Ice Machine Co., ${ }^{54}$ in 1915, the Supreme Court pointed out that a conditional sale passes title only upon complete performance of the contractual terms; ${ }^{55}$ accordingly, the Court reasoned, goods conditionally sold to the debtor were not his "property" and so could not be preferentially transferred by subsequent recordation or repossession." Conceptualism thus permitted a conditional vendor to recover his goods despite the losses caused other creditors by the vendor's failure to record or otherwise give notice of the specious nature of the debtor's apparent rights in the property. ${ }^{57}$

islation invalidated unregistered conveyances only against bona fide purchasers. There are eighteen jurisdictions with such statutes today: CAL. Crwr Cons $\$ 1214$ (Dering, 1941); DEL. REv. CODE $\$ 3680$ (1935); GA. CODE AxN. $\$ \S 22-401,67-109$ (1938); Idago Code ANN. \$54-\$12 (1932); INd. Star. Arrs. \$56-119 (Burns, 1933); Iowa CoDE $\$ 558.41$ (1946); MIrCH. STAr. ANar. \$26.547 (Henderson, 1937); Mont. Rev. Code ANN. \$6935 (1935); Neb. Rev. Stat. \$76-238 (1943); Nev. Coגrp. Laws $\$ 1498$ (1931-1941 Supp.); N.Y. ReAL Prop. LAw \$291 (Afckinney, 1945); Onto Gen. Cone \$ \$572-31 (Page, 1938); OnzA. Stat. Asw., tit. 16, \$15 (1937); S. D. CODE $\$ 51.1620$ (1939); UTAH CODE ANn. \$7\$-3-3 (1943); WASH. Rew. STAr. Ams. $\$ 10596-2$ (Remington, 1933) ; Wrs. Star. \$235.49 (1945); Wyo. Cosrp. Srat. Ax:. $\S 66-119$ (1945). See generally: GLENN, MForTosGes $\$ \$ 368,576$ (8th ed, 1923); 1 WIITSIE, Mortgages $\$ \S 262,266$ (Fribourg and Elting, 5th ed. 1939); Note, 13 Com. L. REv. 539 (1913).

This sole retention of the bona fide purchaser test in the proposcd amendment "proves either (1) that the general theory is incorrect, or (2) that it is correct save as to real property transfers, i.e., that the only case where Congress can and ought to change property rights fixed by the state is the case of an unrecorded realty transfer for an antecedent debt where by local law such transfer could not be successfully attaclied by a lien creditor, or (3) that the exception should not be made." Martin, Substanfive Rcgulation of Security Devices stnder the Bankruptcy Act, 48 CoL. L. Rev. 62, 69 (1948).

52. National Conference of Cosamissioners on Untromar State Lavis, Repoms o:: UNIFORM CHATTEL MORTGAGE ACT 13-9 (1923); Legis., 19 VA. L. Rev. 635, 637 (1933) (statutory summary). See Uniforar Chattza Mortgage Act $\$ 5$.

53. 44 Stat. 666 (1926).

54. 239 U.S. 268 (1915).

55. Bailey v. Baker Ice Mrachine Co., 239 U.S. 268, 274 (1915). See Esmrcz, Irstallatent Sales $\$ \$ 480,507$ (1926); 3 Jones, Chatrer aroztgages ard Co:idituo:iar. SAIES $\$ 1140$ (1933).

56. The Bailey case dealt with a belatedly recorded transfer. That repossession by the conditional vendor at any time before bankruptcy did not constitute a voidable preference, see In re Johnson, 282 Fed. 273 (N.D. Iowa 1922).

57. The Uniform Conditional Sales Act $\$ 5$, which invalidates an unfiled conditional sale as to purchasers from the buyer and his lien creditors, has been adopted by the follow- 
In the hearings on the Chandler Act, there was little doubt that the revamped statute would terminate the immunity of unrecorded conditional sales contracts. ${ }^{53}$ Indeed, the Bailey case was explicitly mentioned as one of the major decisions sought to be "overruled." $" 9$

In the drafting process, however, the Bailey problem was apparently overlooked. Nowhere in the statute is there specific provision for the conditional sale and perhaps in consequence, there has been no challenge since 1938 of the Bailey rule. The Chandler Act's catch-all definition of a "transfer" may, however, be sufficiently broad to bring the conditional sale fortuitously within the orbit of Section 60. A transfer now includes:

". . the sale and every other and different mode, direct or in-
direct, of disposing of or of parting with property or with an interest
therein . . . absolutely or conditionally, voluntarily or involunta-
rily (by any means whatsoever) . .."

Before recordation of a conditional sale or repossession thereunder, the vendee has the legal power of transferring perfect title to a bona fide purchaser or mortgagee. ${ }^{61}$ Since either recordation or repossession by the conditional vendor divests the debtor of this legal power and simultaneously perfects the former's security interest, ${ }^{62}$ the argument is tenable that an "interest" passes and, accordingly, a "transfer" is effected within the meaning of Section 60.63

ing jurisdictions: Alaska, Arizona, Delaware, Hawai,, Indiana, New Hampshire, New Jersey, New York, Pennsylvania, South Dakota, West Virginia, Wisconsin. 2 U. L. A. 6 (1946 Supp.). Twenty-two states have similar statutory requirements: Alabama, Colorado, Connecticut, Georgia, Florida, Iowa, Kansas, Maryland, Minnesota, Missouri, Montana, Nebraska, North Carolina, North Dakota, Ohio, Oklahoma, South Carolina, Texas, Vermont, Virginia, Washington, Wyoming. Absent recording acts, a conditional sale generally is good against bona fide purchasers from the vendee and his creditors. See 1 Williston, SAles $\$ 327$ (1924).

Without this conceptualistic difficulty, the trustee nevertheless could not move against belatedly recorded transaction if the local statute, in the manner of the Uniform Conditional Sales Act $\S 5$, invalidated unrecorded conditional sales only as against the vendee's lien creditors and bona fide purchasers. Bailey v. Baker Ice Machine Co., 239 U.S. $268,275-6$ (1915).

58. 3 Collier, BankRuptcy 941; McLaughlin, Aspects of the Chandler Bill to Amend the Bankruptcy Act, 4 U. of C.HI. L. REv. 369, 393 and n. 120 (1937).

59. Hearings before Committee on Judiciary on H. R. 8046, 75th Cong., 1st Sess. 124 (1937).

60. Section $1(30)$. That this section was redrafted in 1938 to effectuate the new policy of $\S 60$, see H. R. Rep. No. 1409, 75th Cong., 1st Sess. 5 (1937); Weinstern, TuE BANKRUPTCY LAW of 19387 (1938). But there is no evidence of intent to cover the Bailey case specifically.

61. Uniforar Conditional Sales Act $\$ 5$.

62. Ibid.

63. This rationale is supported by 3 ColzIER, BANkruptcy 942-3; Mulder, Ambiguities in the Chandler Act, 89 U. of PA. L. REv. 10, 24 (1940); and Snedeker, Security DCvices and Sec. $60 \mathrm{~A}$ of the Chandler Act, 22 ORE. L. Rev. 307, 318 (1943). Note the 
The unrecorded conditional sale constitutes as iniquitous a secret lien as the undisclosed chattel mortgage; neither satisfies the standard of publicity essential to fair treatment of all creditors. Where bankruptcy condemns the one as a preference, it should not tolerate the other because of casuistry compounded by forgetfulness. Assuming that the conditional sale may, on the above rationale, be numbered among those security transactions for which Section 60 requires publicity, the proposed amendment would not reduce the trustee's powers of avoidance in jurisdictions following the Uniform Conditional Sales Act, for under that statute both bona fide purchasers and lien creditors are protected from unrecorded conditional sales. ${ }^{64}$

\section{The Trust Receipt}

In the typical tripartite trust receipt arrangement, title to the goods passes directly from the manufacturer or exporter to the banker-"entrustor" who has advanced the purchase price; the latter releases the property by way of bailment to the dealer-"trustee" who signs a trust receipt unconditionally agreeing to repay the purchase price plus commission. ${ }^{\text {"s }}$

Supreme Court's declaration that the draftsmen of $\$ 60$ in 1938 were "fully aware of the vicissitudes of its predecessors," noting that in committee hearings, "disapproving reference was made to Bailey v. Baker Ice Machine Co. ..." Corn Exchange National Banl: \& Trust Co. v. Klauder, 318 U.S. 434, 438 and n.11 (1943). That $\$ 60$ cannot be used to invalidate a belatedly filed conditional sale, see Foreword by Hann to Koessler, Assignment of Accounts Receivable, 33 CALIF. L. Rev. 40, 45 (1945); Hannz, Some Unsolved Problens Under Section 60A of the Bankruptcy Act, 43 CoL L. REv. 58, 69 (1945) (but repossession within four months is a voidable preference); 2 GLE:iz, FrauDULENT CONWEYANCES AND PREFERENCES $\$ 518$ (not even repossession within four months is a preference); Glenn, The Conditional Sale at Common Law, 25 VA. L. REv. 559, 585 (1939) ; Note, 28 VA. L. REv. 395, 402 (1942) (". . . it may be presumed that such contracts are without the scope of this section of the Act."). "Can it be said that the loss of a power to do an illegal act is a transfer within the meaning of Section 1 (30) ?" Hanna, Some Unsolved Problems ander Section 60A of the Bankruptcy Act, 43 CoL L. REv. 58, 68 (1943).

Professor Hanna suggests that Section 1 (30) "be amended to include in the category of transfers 'record of any transfer'" Foreword by Hanna to Koessler, sisfro, at 45. But this would not supply the interest in the debtor's ourn property now said to be lacking in both the conditional sale and the trust receipt, discussed pp. 841-2 infro.

64. UNIFORAS CoNDITIONAL SALES ACT $\$ 5$ (adopted by ten states, with twenty-two other states having statutes similar in this respect). See note $\mathbf{5 2}$ supra. See Able, Conditional Sellers, Hostile Clainants and the Filing Period, 47 W. VA. L. Q. 73 (1941).

The suggested lien creditor test would perhaps threaten the trustee's powers in states where case-made law only invalidates the conditional sale as to certain classes of third parties. 1 WIILISTON, Sales $\$ \$ 325-6$ (1923) lists Illinois, Kentuchy, Louisiana and Michigan, which by judicial fiat have brought the conditional sale within other recording acts or otherwise invalidated it against bona fide purchasers. It is possible under these circumstances for the conditional sale to be void against bona fide purchasers, but valid against the vendee's lien creditors, hence beyond reach of the trustee under the preposed amendment. Compare Praeger v. Emerson-Brantingham Implement Co., 122 Md. 303, 89 Atl. 501 (1914) with Lincoln v. Quynn, 68 Mid. 299, 11 Atl. 848 (18s8). Mlaryland now requires recordation against both bona fide purchasers and lien creditors. Mid. Aswi. CoDE, Art. 21, \$71 (Flack, 1939).

65. See, generally, 9 U.L.A. 665-71 (1940) (Commissioners' Prefatory Note to 
The same difficulty over definition of the term "interest" discussed in connection with the conditional sale applies to the trust receipt. Yet, so far as the policy of Section 60 is concerned, there is no distinction between the secretly executed trust receipt and the unrecorded conditional sale or chattel mortgage in those jurisdictions which compel the public registration of all three transactions. ${ }^{66}$ The Uniform Trust Receipts Act, adopted by twentyone states, ${ }^{67}$ requires the filing of a statement of the trust receipt within thirty days for protection against lien creditors of the dealer-trustee; ${ }^{\text {cs }}$ repossession has the same effect as filing. ${ }^{69}$ Following the rationale employed with respect to the conditional sale, it would seem that perfection of the creditor's security either by repossession or recordation may today constitute a "transfer" of an interest in the debtor's property, voidable if the elements required by Section 60 were present at that time..$^{70}$

The proposed amendment does not appear to curtail the trustee's power with respect to the trust receipt which is not perfected by repossession or recordation until within four months before bankruptcy. The lien creditor is expressly protected from secretly executed trust receipts by the Uniform Act. ${ }^{11}$

\section{The Bailment and Consignment}

Unlike the conditional sale and the trust receipt, the bailment does not contemplate an absolute obligation by the bailee to pay for the goods delivered. A bailment is merely a delivery of goods for a temporary and limited

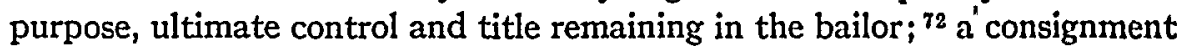

Uniform Trust Receipts Act); 2 Glend, Fraudulent Conveyances and Preferences $\$ \S 556-64$; Vold, Sales $\$ \$ 111-8$ (1931); 1 Williston, Sales $\$ \$ 338$, 338a; Bogert, The Effect of the Trust Receipts Act, 3 U. of CHr. L. REv. 26 (1936); Frederick, The Trust Receipt as Security, 22 CoL. L. Rev. 395, 546 (1922) ; Hanna, Trust Receipts, 19 CaLIF. L. Rev. 257 (1931) (disapproves of recording statutes) ; Stone, The "Equilable Mortgage". in New York, 20 CoL. L. Rev. 519, 533 (1920). For the trust reccipt in bankruptcy, see 3 Collter, Bankruptcy 953-8; Comment, 45 Yale L. J. 1272 (1936); Note, 26 CoRN. L. Q. 306 (1941) ; Legis., 82 U. of PA. L. Rev. 270 (1934) (Uniform Trust Receipts Act).

66. Note, however, Professor Hanna's firm assertion that the "inherent nature" of the trust receipt places it beyond the legitimate field of recording acts. Hanna, Extension of Public Recordation, 31 Cor. L. Rev. 617, 633-5 (1931).

67. California, Connecticut, Idaho, Illinois, Indiana, Maryland, Massachusetts, Minnesota, Montana, Nevada, New Hampshire, New Jersey, New York, North Dakota, Oregon, Pennsylvania, South Dakota, Tennessee, Utah, Virginia, Washington. 9 U. L. A. 123 (1946 Supp.).

68. UNIFORA TRUST RECEIPTS ACT \& \&

69. UnIFORAS TRUST Receipts Act $\$ 7$.

70. The only case in point held that repossession within four months before bankruptcy did not constitute a preference, since title remained in the entrustor. Walton v. Commercial Credit Co., 69 S.D. 263, 267, 9 N.W.2d 266, 268 (1943). South Dakota, however, had not at the time, adopted the Uniform Trust Receipts Act.

71. UNIFORM TRUST ReCEIPTS ACT \&7.

72. Bays, Bamments, Shipdient and Sale of Personal Property $\$ 58$ (1935); 3 Jones, Chattec Mortgages $\$ 972$ (1933). 
is a bailment for sale to the consuming public.73 Since there is no debtorcreditor relation, essential to the present statutory definition of a voidable preference, ${ }^{74}$ it has been uniformly held that the trustee cannot invalidate a bailment or consignment regardless of the applicability of local recording statutes. ${ }^{75}$

In those jurisdictions which have modified the common law validity of the bailment against third parties by bringing it within the scope of the recording acts, ${ }^{76}$ the unpublicized bailment, like other secret liens, should seemingly fall within the purview of Section 60 . To continue the present immunity invites the casting of other security transactions in bailment form in order to escape condemnation as preferential transfers. The proposed amendment, by changing the perfection test, obviously does not remedy the defect here discussed. Revision of Section 60 specifically to include repossession under an "unperfected" bailment or its belated recordation would seem necessary. $\pi$

\section{Assignment of Accounts Receivable}

The assignment of accounts receivable presents an unusual publicity problem from the standpoint of Section 60 . Until recently, creditors could learn of their debtor's assignment, only indirectly through notification by the assignee to the account obligor. ${ }^{78}$ Yet in the typical transaction developed by

73. 1 Glenn, Fraudulent Conveyances and Prererences $\$ \S 535-6$; 3 Jo:ies, CenatTEL MIORTGages $\$ 964$.

74. "A preference is a transfer ... to or for the bencfit of a creditor ... by [a] debtor ... ." Section 60 .

75. Firestone Tire and Rubber Co. v. Cross, 17 F.2d 417, (C.C.A. 4th 1927). See cases cited, 3 Collier, BaNkRUptCy 949 n.13.

76. S. C. CIV. CODE $\$ 7047$ (1942), specifically requires public recordation of bailments. Other states, by judicial fiat, have brought the bailment within the scope of the recording acts: Alabama, Illinois, Kentucky, Missouri, Tennessee. See 6 C. J. 1105 \$31, 8 C. J. S. 251 \$1S and cases cited. See 2 A U. I. A. \$ 55 (1924).

Some southern states have Traders Acts which compel the public display of the legal owner's name at the place of sale. Violation of the statute permits creditors of the bailee to treat the property as the latter's own. MD. Arrs. Cons, Art. 2, \$§ 18, 20 (Flack, 1939); Míss. CODE ANN. \$273 (1942); VA. Code ANN. \$5224 (Michie, 1942); W. VA. CODE

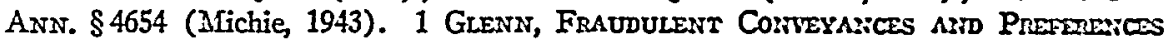
$\S 363$.

77. The following inclusion, after the first sentence in $\S 60_{2}$ is suggested: "Provided, however that a preference shall also include a transfer of any property held by the bankrupt as a consigned bailee or lessee (or in any other capacity) for resale to the consignor, bailor or lessor, with those consequences enumerated above." Section $60 \mathrm{~b}$ would also have to be amended to include "consignor, bailor or lessor" within the scope of the word "creditor."

78. The court in the Klauder case realized that notification of the obligor would scarcely warn all creditors, but viewed the establishment of so low a publicity standard as irrelevant. Corn Exchange National Bank \& Trust Co. v. Klauder, 318 U.S. 434, 441 (1943). See Note, 10 U. of CHI. L. Rev. 220 (1943). But see Hanna, Some Unsolved Problems Under Section 60A of the Baskruptcy Act, 43 Cor. L. Rev. 58, 62-70 (1943). 
the commercial banks, the account debtor was not notified, the borrowerassignor assuming the responsibility of collecting the sums due on the assigned accounts and applying the proceeds to the loan..$^{79}$

In the absence of statutory regulation, three prevailing rules govern the effect of non-notification on the rights of assignees of accounts receivable..$^{80}$

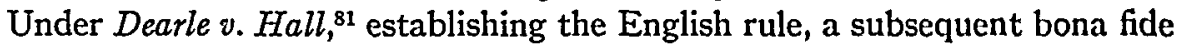
purchaser who first gives notice to the account debtor prevails over a prior but non-notifying assignee. ${ }^{82}$ Taking the opposite extreme, the New York rule does not require notice in order to perfect the assignment; ${ }^{83}$ a subsequent assignee, regardless of his good faith or lack of knowledge, is accountable to the first assignee for all collections from the obligor. ${ }^{84}$ The Massachusetts rule, followed by the federal courts ${ }^{85}$ prior to Erie v. Tompkins 80 and approved by the American Law Institute, ${ }^{87}$ does not demand notifica-

79. Commercial banks, which had been seeking additional outlets for investmeat capital, developed non-notification financing in the period after World War I, in order to accommodate prospective borrowers who were unwilling to risk the publicity usually attending factor financing. Non-notification financing now totals about $\$ 1,000,000,000$ annually. Saulnier and Jacoby, Accounts Receivable Financting 3-4 (1943). Sec also Comment, 44 YALE L. J. 639 (1935).

80. For discussion of the case-made law which governs in only nineteen jurisdictions, see Wriciston, Contracts $\$ 435$ et seq. (rev. ed. 1936); Brinck, Accounts Receivablc as Collateral, 11 WASH. L. REv. 134 (1936); Laucheimer, Some Problems of Modarn Collateral Banking, 26 CoL. L. Rev. 129 (1926); Miller, An Assignment of Accounts Receivable as a Security Device, 22 MARQ. L. REv. 28 (1937) ; Comment, 33 YALE L. J. 767 (1924) ; Note, 24 CoL. L. Rev. 501 (1924). For classification of the three rules according to jurisdiction see American Bankers Association, Accounts Recemvanle: Lists of States. (July, 1944) (most recent and exhaustive report); NATiONAL. Association of Credit Men, Credit Manual of Commarcial Laws 230-2 (1944); Robert Morrus Assoctates, Bulietin 277-8 (1944) ; Committee of N.Y. BAR Ass'n., Report on UniFORAr St. LAws 2-4 (1943) ; Notes, 31 A.L.R. 876 (1924), 110 A.L.R. 774 (1937).

81. 3 Russ. 1 (Ch. 1827). A leading United States case is In re Phillips' Estate, $205 \mathrm{~Pa} .515$, 55 Atl. 213 (1903). The English rule is still followed in Delaware (probably), District of Columbia, Kansas (probably), Louisiana, Mississippi, Nebraska, Tennessee, Vermont. Anierican Bankers Association, Accounts Recervable: Lists of StAtes (1944).

82. The negligence of the first assignee in failing to notify the obligor is considered so conducive to the assignor's fraud and misrepresentation that the assignee is estopped from asserting his title. Dearle v. Hall, 3 Russ. 1 (Ch. 1827). See Crane, Recenl Stalutory Changes in the Law of Chattel Security, 8 U. of PrTr. L. REv. 104 (1942).

83. Fortunato v. Patten, 147 N.Y. 277, 41 N.E. 572 (1895). Only New York follows this rule. American Bankers Ass'n., Accounts Recervanle: Lists of States (1944).

84. Superior Brassiere Co. v. Zimtbaum, 214 App. Div. 525, 212 N.Y.S. 473 (1st Dep't 1925).

85. Salem Trust Co. v. Manufacturers Finance Co., 264 U.S. 182 (1924). Comment, 33 Yale L. J. 767 (1924). See Notes, 13 Calif. L. Rev. 141 (1925), 24 Col. L. Rev, 501 (1924).

86. 304 U.S. 64 (1937).

87. Restatenent, Contracts $\$ 173$ (1932); note 22 supra. The Supreme Court in the Salem case did not confine the exception to these situations specifically set out by 
tion in order to perfect the assignment but estops the first assignee from asserting his title under certain prescribed conditions. ${ }^{\varepsilon 9}$

Although the draftsmen of the Chandler Act do not appear to have considered specifically the effect of the 1938 amendment upon assignments of accounts receivable, ${ }^{\S 9}$ the generally expressed intent to invalidate all types of secret liens, ${ }^{80}$ was sufficient basis for the Supreme Court in the Klazder case. $^{91}$ That decision permits the trustee to invalidate an assignment executed in jurisdictions following Dearle v. Hall, if the creditor-assignee has not notified the account-debtor. As earlier suggested, this conforms with the basic aim of Section 60 -to require from all creditors the public notoriety of their transfer demanded by local law. ${ }^{92}$

the A.L.I. but rested its decision more broadly on general principles of equitable estoppel. 88. See note 22 supra. The rule is still followed by Iowa, Kentucly; Montana (probably), New Jersey, and West Virginia. Arrerican Bankers Ass'si, Accousits RECEIVABLE: IISTS OF STATES (1944).

89. Apparently through an oversight for which Professor ArcLaughlin apologizes. McLaughlin, Defining a Preference in Bankruptcy, $60 \mathrm{HARv}$. L. KEv. 233, 245-6 and n.31 (1946).

Legislators soon realized the possibility of applying $\$ 60$ to accounts receirable, however. An amendment was introduced in 1940 to except this transaction from the bon fide purchaser test of perfection but was buried in committee. S. 3554, 76th Cong., 3d Sess. (1940).

Commentators have compensated for the draftsmen's failure to consider the position of assignment of receivables in bankruptcy. See Bennett, Assignment of Accousts Receivable Under the Chandler Act, 44 Coss.I. J. 404 (1939); Cohen and Gerber, Jfortgages of Accounts Receivable, 29 Gro. L. J. 555 (1941); Douglas, Assigncd Accounts as Affected by Section 60a of the Banknuptcy Act and the Prozisions of State Law uith Reference Thereto, 19 J. N. A. REF. BANKR 11 (1944); Hamilton, Effect of Sction Co upon Assigned Accostnts Receivable, 26 VA. L. Rev. 169 (1939); Kupfer and Livingston, Com Exchange National Bank v. Klauder Recisited, 32 VA. L. Rev. 910 (1946); AcLaughlin, Defining a Preferentce in Bankruptcy, $60 \mathrm{HARv}$. L. REv. 233, $249-50$ (1946); Mulder, Ambiguities in the Chandler Act, 89 U. of PA. L. Rev. 10, $25-6$ (1940); Neuhof, Assignment of Accounts Receivable as Affected by the Cliandler Act, 34 Ins. L. Ror. 538 (1940); Comment, 26 VA. L. REv. 168 (1939).

Since the early amendments of $\S 60$ were concerned only with state recordation statutes, and assignments of accounts receivable were formerly governed solely by judicial decision, there was until 1938 no question of their validity, provided that, when executed, they were not voidable preferences, and did not constitute fraudulent conveyances within the doctrine of Benedict v. Ratner, 268 U.S. 353 (1925). Petition of National Discount Co., 272 Fed. 570 (C.C.A. 6th 1921), cert. denied, 257 U.S. 635 (1921) ; Robertson v. Hennochsberg, 1 F.2d 604 (W.D. Tenn. 1924) and cases cited. See 3 Corrmes, Bambrumter 963-4.

90. Hearings before Committee on the Judiciary an H.R. 8046, 75th Cong., 1st Sess. $122-5$ (1937) ; H.R. REP. No. 1409, 75th Cong., 1st Sess. 30 (1937).

91. See note 29 supra.

92. See p. 832 supra. According to Professor Hanna, non-notification financing, regardless of local law, is not properly classified as a secret lien: "Most tall of secret liens seems to belong to a dream world." Credit is extended, he argues, not on the basis of the debtor's visible assets, but on his financial statements and information furnished by credit services. Hanna, Some Unsolved Aspects of Section $60 \mathrm{~A}$ of the Banlerupley Act, 
It will be recalled that the rationale of In re Vardaman would allow the trustee similarly to invalidate an assignment executed in jurisdictions adopting the Massachusetts rule, if the assignee has failed to notify the account debtor. The hysteria which greeted In re Vardaman proved, however, unwarranted; three years later, the problem was again considered in the federal courts. ${ }^{93}$ This time, a conflict of laws difficulty required the court to ground its decision on the Massachusetts, the English or the New York rule. Assuming, arguendo, that the Massachusetts rule applied, with the resultant possibility that a subsequent bona fide purchaser (assignee) could acquire an interest superior to that of the creditor-assignee by taking some action against the obligor, the district court rejected the Vardaman rationale, refusing to pile hypothesis on speculation to the destruction of the statute's purpose. ${ }^{94}$

The Circuit Court of Appeals affirmed, grounding its opinion on the lower court's finding that the assignment had been perfected, under controlling New Jersey law, when executed. While voicing no express stand on In re Vardaman, the court left little doubt of its condemnation of that anomalous decision. ${ }^{95}$ Although the trustee's petition squarely raised the issue of the Vardaman rationale, ${ }^{96}$ the Supreme Court denied certiorari..$^{97}$

43 CoL. L. Rev. 58, 69 (1943); Hanna, Extension of Public Recordation, 31 Cor. L. Rev. 617, 623-30 (1931). Inspection of questionnaires used by Dun \& Bradstreet, however, indicates the importance with which credit rating agencies view the assignment of accounts. A questionnaire submitted by the American Bankers Association to bankers in Missouri and California which have adopted recordation statutes, asked: "Can financial statements be a satisfactory substitute for a filing statute generally, and for a bank which, as an unsecured creditor, wants to know promptly when a borrower assigns his accounts?" Replies from both states were emphatically in the negative. LEGAL DEPT., AMER. BAnirens Ass'n, Reports on Operation of Filing Statutes in California and Missouni 2 (Jan, 1947). For another view as to the efficacy of financial statements, see Emory and Shattuck, Assigned Conditional Sale Contracts and Acconnts As Collatcral, 11 Wasn. L. REv. 181, 190-1 (1936).

93. In re Rosen et al., 66 F. Supp. 174 (D.N.J. 1946), aff'd, 157 F.2d 997 (C.C.A. 3d 1946), cert. devied, 330 U.S. 835 (1947).

94. ". . . I do not construe [the Klauder case] ... to imply that the lower courts may imagine conditions which have no foundation in fact. To do so would be to maled the subject ridiculous. ... This court cannot imagine... the absence of a validly consummated assignment . . . when one actually exists, nor can it imagine impossible or unlawful conduct on the part of the parties thereto..." In re Rosen $c t$ al., $66 \mathrm{~F}$. Supp. 174, 179 (D.N.J. 1946).

95. "... the favored position acquired by the subsequent assignee in the situations noted in Restatement Contracts (1932) $\$ 173$, comes not from his status as a bona fidc purchaser, but from his activities following his belated assigmment." In $r \varepsilon$ Rosen ct al., 157 F.2d 997, 1001 (C.C.A. 3d 1946) (italics added).

96. Petition for Writ of Certiorari, pp. 6-7, In re Rosen et al., 157 F.2d 997 (C.C.A. 3d 1946).

97. 330 U.S. 835 (1947). In the Klauder decision, the Supreme Court noted that “. . many states do not require notice to the debtor to foreclose possible superior rights of subsequent assignees," citing 2 Wirliston, ConTrActs $\$ 435$ (Rev. Ed. 1938) (discussing Massachusetts and English rules). 318 U.S. 434, 441 (1943). This would 
Reacting to the Klauder decision and its application in In re Vardaman with surprising alacrity, twenty-nine states have passed legislation dealing with the assignment of accounts receivable. ${ }^{13}$ The first type, supported by the American Bar Association and patterned after the New York rule, "validates" the assignment when executed and provides that a subsequent assignee who collects from the obligor is accountable to the first assignee.5 Unless its original execution constitutes a preference, an assignment in jurisdictions adopting this statute cannot be attacked under the Chandler Act. ${ }^{150}$ Recordation statutes, suggested by the American Bankers Association ${ }^{101}$ and adopted by twelve jurisdictions, ${ }^{102}$ provide for perfection of the assignment by filing of notice with the local authorities. ${ }^{103}$ The third type requires an

seem to imply that the trustee could not invalidate an assignment in jurisdictions following either the Massachusetts or the New York rule.

98. For extensive discussion of these statutes, see Douglas, Assigucd Accounts as Affected by Section 60a of the Bankruptcy Act and the Provisions of State Law writh Reference Thereto, 19 J. N. A. ReF. BANKR. 11 (1944); Koessler, Assignment of Accossnts Receivable, 33 CALIF. L. REv. 40 (1945) (pro and con: recordation v. validation type of statute) ; Koessler, New Legislation Affecting Non-Notificalion Firancing of Accounts Receizable, 44 Mrce. L. Rev. 563 (1946) ; Montgomery, Revirw of Sufrcme Court Ruling on Assignment of Accoututs Receiruble, 17 J. N. A. REr. BAsikr. 119 (1943); Crane, Recent Statutory Changes ist the Law of Chattel Security, 8 U. of Prrr. L. REv. 104 (1942) (discussing Pennsylvania bookmarking statute); Comments, 9 Afo. L. REv. 167 (1944) (analyzing Missouri recordation statute), 17 So. CALIF. L. REv. 303 (1944) (analyzing California recordation statute).

99. Fifteen states have adopted such legislation: Ark. Laws 1945, No. 118; Cown. Gent. Stat. \$644g (Supp. 1943); IrI. Star. ANx., c. 1211/2, \$§ 220-2 (Jones, Supp. 1947) ; Ind. Stat. Ann. \$\$ 19-2101-19-2104 (Burns, Supp. 1945); MIaine Laws 1945, c 100; MId. Code Ann., Art. 8, \$1A (Flack, Supp. 1943) ; MLnss. Stst. Arzo, c. 107A,

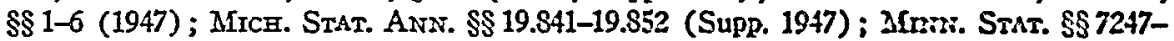
11-7247-15 (Miason, Supp. 1946) ; N. H. Laws 1945, c. 19; Ore. Coxip. LAws Awn. S 623101 (Supp. 1947) ; R.I. Acrs 1943, c. 1345; S. D. Laws, c. 213 (1945); VA Cone Aris. \$5767a (Supp. 1946); Wis. Laws, c. 206 (1945).

100. Under the New York rule, after which the "validation" statutes are patterned, an assignment is "made" when executed, without notification to the obligor. Rodmore v. Lehman, 129 F.2d 892 (C.C.A. 2d 1942), rezicrsing 128 F.2d 564 (C.C.A.2d 1942).

101. Legal Dept., Aster. Bankers Ass'n, Accounts Recervadle-Funivg Statures, TENTATIVE Draft (Feb., 1947).

102. Cat. CIv. Cone $\$ \$ 3017-29$ (Deering, Supp. 1947); Colo. Laws 1947, c. 120; Fla Laws 1947, c. 24297; Idaho Laws 1945, c. 172; Mo. Rev. Sr.1r. Asz:. \$3 3347.1-3347.6 (Supp. 1947) ; OHIo Gen. Code AnN. \$§ \$509-3-\$509-6 (Page, Supp. 1947); Orzn. Star. ANN., tit. 15, §§631-7 (Supp. 1947) ; S. C. Laws 1946, No. 433; TEx. REr. StAr. Axr:.,

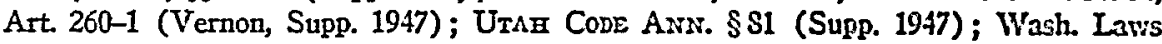
1947 , c. $\$$. An amendment to $\$ 70$, proposed since this comment was written and coupled with the Hobbs bill proposing revision of $\$ 60 \mathrm{a}$, would invalidate as against a trustee in bankruptcy, all assignments of accounts not filed with the proper federal district court, in lieu of individual state recording acts. H.R. 5834, s0th Cong., 2d Sess. (1948).

103. The notice usually must state the names and addresses of the prospective or actual assignor and assignee. Details as to the nature and amount of the accounts assigned are not required. 
appropriate notation on the books of the assignor..$^{104}$ Where there are either bookmarking or recordation acts, the Klauder decision still governs; an assignment is not "made" until the assignee has completed that act of perfection demanded by local law.

Where the rule of Dearle v. Hall is held not to prefer the assignor's lien creditors over the assignee, regardless of non-notification of the accountdebtor, ${ }^{105}$ the proposed amendment would nullify the Klander decision. This result would be the same as that now obtaining under the Massachusetts and New York rules and "validation" statute. No change in the present law would occur, however, in those jurisdictions following the English rule which do subject assignments, under such circumstances, to the claims of the assignor's creditors. ${ }^{106}$ Moreover, since recordation statutes explicitly protect creditors of the assignor from unpublicized assignments, the suggested perfection test would still enable the trustee to invalidate belatedly filed transfers of accounts receivable in these states.

\section{The "Imperfectible" Transfers}

Some security transactions are virtually "imperfectible" according to literal construction of the test prescribed by the Chandler Act. Despite full recordation in compliance with the applicable statutes, the conditional sale for resale, ${ }^{107}$ the freehanded mortgage of stocks in trade, ${ }^{103}$ the trust receipt ${ }^{103}$ and the factor's lien ${ }^{110}$ can never be validated against bona fide purchasers without notice; the latter are relieved by both judicial and statutory law from the burden of checking local records to ascertain whether their purchases, made in the ordinary course of trade, are free from prior claims. The secured creditors in such situations can never completely "perfect" the transaction. Must these transfers $a$ fortiori be treated as occurring immediately before bankruptcy, at which time the elements of a preference are determined? The advocates of the proposed amendment so insist, ${ }^{111}$ despite the lack of any case so holding.

104. Ga. Code Ann. $\$ 85-1803$ (Supp. 1945) ; Pa. Stat. Ann., tit. 69, \$\$ 561-3 (Purdon, Supp. 1946).

105. Garford Motor Truck Co. v. Buckson, 4 Harr. 103, 143 Atl. 410 (Del. 1927); Hall v. Kansas City Terra Cotta Co., 97 Kan. 103, 154 Pac. 210 (1916); Schoolficld v. Hirsh, 71 Miss. 55, 14 So. 528 (1893); Lewis v. Holdredge, 56 Neb. 379, 76 N.W. 890 (1898). See 2 WLLISTON, Contracrs $\$ 434$ and n.2 (rev. ed. 1936).

106. Golsan v. Powell, 32 La. App. 521 (1880); Dillingham v. Traders' Ins. Co., 120 Tenn. 302, 108 S.W. 1148 (1908); Wolcott v. Mongeon, \&8 Vt. 361, 92 At1. 457 (1914). Thus the proposed amendment would fall short of its own intended objective. Sce Hanna, Preferences in Bankriptcy, 15 U. of CHr. L. REv. 311, 322 (1948).

107. Untforar Conditional Sales Act $\$ 9$.

108. 2 Glenn, Fraudulent Conveyances and Preferences $\$ \$ 582-94$; Cohen and Gerber, Mortgages of Merchandise, 39 CoL. L. REv. 1338 (1939); Snedeker, Security Devices and Section 60A of the Chandler Act, 22 ORE. L. REv. 307, 324-6 (1943).

109. UNIForm Trust Receipts Act \&9-2 (a). See Note, 26 CoRn. L. Q. 306 (1941).

110. New York Personal Property Law $\$ 45$.

111. See commentators cited note 32 supra. Professor Hanna in his latest article, 
Certainly the history of legislative reform preceding the Chandler Act and a scrutiny of committee hearings and reports indicate that the present Section 60 was intended only to "insure a compliance with whatever public notice is required by local law." 112 When the creditor so complies, the transfer should be treated as perfected. The essence of the conditional sale for resale, the freehanded mortgage, the trust receipt and the factor's lien is the expectation that the goods will be sold to the consuming public, free from prior liens. Consequently, the possibility of a bona fide purchaser in the ordinary course of business is irrelevant in considering the perfection test prescribed in Section 60. But the interest conveyed is fully perfectible against purchasers, other than those in the ordinary course of trade, and the debtor's creditors by recordation in compliance with local law. Construction of Section 60 in the light of its overall purpose would make this compliance the test of perfection.113

The proposed amendment, attempting to secure "imperfectible transfers" against attack, would achieve only partial success. The rationale which protects the bona fide purchaser as against the entrustor, mortgagee of stoclss in trade or conditional vendor of goods for resale is extended by many jurisdictions to lien creditors of the conditional vendee 114 and mortgagor. ${ }^{115}$ Literal application of the suggested perfection test in these jurisdictions would be fraught with those very dangers which critics allege to be inherent in the present Section 60.

If it is really thought that the present act threatens the validity of the

argues that the trust receipt and factor's lien are statutory liens, protected from the operation of $\S 60$ by $\S 6 \% \mathrm{~b}$. Hanna, Preferences in Banknotcy, 15 U. of Cur. L. REv. 311, 320.

112. Weinstetn, The BankRuptcy LaW of 1938, 120 (1938).

113. See Snedeker, Security Dezices as Preferences Under the Bantruptcy Act, 8 Mo. L. Rev. 85, 96, 102-5 (1943); Snedeker, Security Dezices and Scction COA of the Chandler Act, 22 ORE. L. Rev. 307, 326 (1943). 3 CoLster, BAsiknuptcy 958 urges a relaxed application of $\S 60$ in these cases.

114. In these cases, the conditional vendor is said to hold the vendee out to the world as the owner of the goods; he is therefore held estopped from setting up his reserved title against a creditor who may have acted on the basis of the ostensible ownership. Troy Wagon Works Co. v. Hancok, 152 Fed. 605 (C.C.A. 7th 1906); Flint Wagon Worlss v. Maloney, 26 Del. 137 (1911); Di Toco v. Horn, 153 N.Y.S. 93 (Sup. Ct. 1915); Scherl v. Flam, 129 App. Div. 561, 114 N.Y.S. 86 (2d Dep't 1908) ; Peck v. Heim, 127 Pa. 500, 17 Atl. 984 (1889); Star Clothing Mf́fg. Co. v. Nordeman, 118 Tenn. 384, 100 S.W. 93 (1907) ; Loving Pub. Co. v. Johnson, 68 Tex. 273, 4 S.W. 532 (IS87); Newcomb v. Guthrie, 145 Va. 627, 134 S.E. 585 (1926).

But the more general rule, as illustrated by the Uniform Conditional Sales Act $\$ 9$, protects bona fide purchasers only. See 1 Wririston, SALEs $\$ 329$ (1924) and cases cited.

115. The majority rule prefers the mortgagor's creditors over the mortgagee of stocks in trade. Farmers' State Bank v. Kirkland \& Brackin, 200 Ala. 146, 75 So. 894 (1917). For presentation of the rationale and doctrine evolved, see Cohen and Gerber, Mortgages of Merchandise, 39 CoL. L. Rev. 1338 (1939) (cases cited n.14). See also cases cited in Note, 97 A.L.R. 646, 677-80 (1935); 10 A3r. Jur. 782, $\$ 103 ; 14$ C. J. S. $807, \S 203$. 
conditional sale for resale, the freehanded mortgage, the trust receipt or the factor's lien, the statute might easily be amended to take care of this particular situation. To the last sentence of Section $60 \mathrm{a}$ could be added:

"Provided, however, that where the property so transferred was for resale by the debtor in the ordinary course of business, the transfer shall also be deemed to have been made at the time when it was recorded or registered in conformity with procedure available under applicable law, or at the date of execution if recordation procedure is not so available."

This suggestion would except these transfers from application of the bona fide purchaser test by allowing perfection by recordation or, in jurisdictions not requiring publicity, by execution.

The wisdom of rigid interpretation of the present perfection test is also questioned in the case of the pledge where temporary and limited possession of the chattel has been restored to the pledgor. Here, the pledgee is usually protected against the pledgor's creditors, ${ }^{116}$ but bona fide purchasers take free from his prior claim. ${ }^{117}$ The pledge is not analogous to the trust receipt, conditional sale for resale, the freehanded mortgage or the factor's lien. The sole notice which the general public receives is from the actual delivery of possession to the pledgee; the general creditors cannot inspect local records and discover that the pledgor, in temporary possession, really does not own clear title. Consequently, the Chandler Act should deem the transfer "made" only when the pledgee reacquires possession. ${ }^{118}$

The proposed amendment, however, would protect the pleclgee "temporarily out of possession," since his interest is usually superior to that of the pledgor's lien creditor. ${ }^{119}$ This result, in effect, would invite a revival of the secret lien and even fraud; who is to dispute the pledgee's insistence that he had been permitting the pledgor to remain in possession only "for a tempo.

116. Hutton v. Arnett, 51 IIl. 198 (1869); Hilliker v. Kuhn, 71 Cal. 214, 16 Pac. 707 (1896), Clare v. Agerter, 47 Kan. 604, 28 Pac. 694 (1892). See 2 Glens, FruudulENT Conveyances and Preferences $\$ 490$ and cases cited. The pledgce has been protected against the trustee despite the latter's status under $\$ 70$ (c) as a lien creditor with respect to property in the debtor's possession at the time of bankruptcy. Petition of Chattanooga Bank, 261 Fed. 116 (C.C.A. 6th 1919).

117. 2 Glenn, Fraudulent Conveyances and Preferences $\$ 490$ and cases cited; RESTATEMENT, SECURITY §11, comment $c$ (1941).

118. Snedeker, Security Devices and Section $60 \mathrm{~A}$ of the Chandler Act, 22 Ores L. Rev. 307, 322 (1943). Professor Glenn views with great alarm the threatened invalidation of this type of pledge. ". . . at one stroke, a rule of pledge law would be abolished, although it is so well established that the American Law Institute has included it within a Restatement." 2 Glenn, Fraudulent Conveyances and Preferences $\$ 490$. In his latest article, Professor Hanna, however, doubts that the present $\$ 60$ would invalidate this type of pledge; the date of the transaction is determined as of the time it was consummated by the pledgee's possession, regardiess of subsequent retransfer to the pledgor. Hanna, Preferences in Bankruptcy, 15 U. of CHI. L. REv. 311, 320 (1948).

119. See note 116 supra. 
rary and limited purpose"? If his claim cannot be disproved, general creditors will lose out, despite the fact that they have no way of ascertaining the true situation from the pledgor's outward appearance.

\section{Conclusion}

The 1938 revision of Section 60 followed forty years of fruitless effort to outlaw the secret lien; the draftsmen could point to specific case-made results which merited statutory repeal. Now, for the first time in banlruptcy history, the unrecorded real estate mortgage, ${ }^{12 j}$ judgment assignment ${ }^{121}$ and chattel mortgage ${ }^{122}$ have been brought within the purview of the preferential transfer; most significantly, the equitable lien ${ }^{123}$ has been condemned.

With the lone exception of In re Vardaman, these results have been achieved without materialization of the evils allegedly inherent in the present act. Undeterred, however, by reality, the draftsmen of the proposed amendment would sacrifice many of the gains to remedy ailments largely imaginary. ${ }^{124}$ Admittedly, the present statute seems to threaten certain security devices. Interpretation of Section 60 in the light of its objective will, however, avoid any harm. And spot amendments ${ }^{125}$ and appropriate state action ${ }^{126}$ furnish additional safeguards if needed against extreme judicial unreason far preferable to the drastic measure suggested.

But perhaps the most serious disservice performed by the present drive for amendment is negative: it inhibits action against the actual deficiencies in the present law. Unrecorded bailments are almost entirely beyond the trustee's reach. The status of unpublicized conditional sales and trust receipts is at best conjectural. Any pressure for alteration in the statute might better be aimed at including these devices within its scope than at demolishing a structure whose early results have been markedly successful.

It has been pointed out that the proposed amendment reflects "the easy money times of inflation and expanding credit in which we have been liv-

120. Matter of Cox, 132 F.2d 881 (C.C.A. 7th 1943).

121. Matter of Hutcherson, 133 F.2d 959 (C.C.A. 7th 1943).

122. Miatter of Greenberg, 48 F. Supp. 3 (D. MFass. 1942).

123. Matter of Markert, 45 F. Supp. 661 (D. Mass. 1942) ; cf. Gins v. Mlauser Plumbing Supply Co., 148 F.2d 974 (C.C.A.2d 1945).

124. "Certain problems generate an interest for teachers which may lead them to exaggerate the importance of such problems to the business community. . . . Before cmbarking upon further adventures in amendment Congress should have before it detailed information as to the pecuniary dimensions of the evil it proposes to remedy, and as to the probable effect of the proposed amendment on existing types of financing." Martin, Substantive Regulation of Security Devices under the Bankruplcy Act, 48 CoL. L. REv. $62,82,83$ (1948).

125. This suggestion has been rejected by MrcLaughlin, Defining a Prefcrence in Bant:ruptcy, 60 HARv. L. REv. 233, 253-4 (1946) and Keefe, Kelly and Lewis, supro note 4, at 113, but is approved by Martin, sipra note 124, at 83 .

126. Swift state reaction to the Klander decision, supro p. 849, indieates the practical validity of this suggestion. 
ing." ${ }^{127}$ Despite these developments, bankruptcy must still choose between the individually secured creditor who has elected to conceal his interest in the debtor's property and the general creditors who required no protection other than the latter's financial integrity. Equal distribution of the entire insolvent estate compels selection of the general creditor.

127. Oglebay, supra note 1 , at 60 . See speech by Daniel Webster, 8 CoNG. Groue, 26th Cong., 1st Sess. app. 814 (1840). Professor McLaughlin, drawing attention to Webster's speech during House hearings, pointed out the function of the law of preferences in discouraging shaky extension of credit. Hearings before Commiltec on Judiciary on $H . R .8046,75$ th Cong., 1st Sess. 121 (1937). The Supreme Court impliedly has taken cognizance of this function of $\S 60$. See Corn Exchange National Bank \& Trust Co. v. Klauder, 318 U.S. 434, 439-41 (1943). Professor Hanna thinks little of the danger of over-extension of credit and is outraged at the suggested use of $\$ 60$ in this manner: "It is bad enough for the government to interfere with the conduct of individual business for the correction of recognized evils without carrying this intrusion into realms invoking dangers existing only in the inner consciousness of the advisers of the lawmakers." Hanna, Some Unsolved Problems Under 60A of the Bankruptcy Act, 43 CoL. L. REv. 58, 70 (1943). 